\title{
Color Blindness Testing Using A Client-Server Based on The Ishihara Method
}

\author{
Yudhi Ardiyanto*1, Muhamad Yusvin Mustar ${ }^{1}$ \\ ${ }^{1}$ Department of Electrical Engineering, Faculty of Engineering, Universitas Muhammadiyah Yogyakarta \\ Kampus Terpadu UMY, Jalan Brawijaya, Bantul, Yogyakarta, Indonesia \\ *Corresponding author, e-mail: yudhi.ardiyanto@umy.ac.id
}

\begin{abstract}
The Ishihara method is one way to detect whether or not someone suffers from color blindness. This method possesses several sets of plates or circle patterns containing various combinations of colored dots and sizes, forming numbers visible for people with normal eyes. A collection of several plates with the name Ishihara book is available in the market. However, the book has a weakness for being easily damaged or faded in color. Although there are some shortcomings, several researchers have developed applications to anticipate those weaknesses. Being unable to be used by several people at once and the test history has not been adequately archived, are several examples of shortcomings of existing applications. This study aims to create a client-server-based color blindness testing mobile application. The system can provide real-time test results, and detailed test history is presented. Another feature is the push notification menu that sends messages to all users. This application has been designed and implemented successfully. Thereby, it can be used for a color blindness test before conducting a medical examination.
\end{abstract}

Keywords: Color Blindness, Client-server, Ishihara method

\section{Introduction}

One of the requirements to participate in selecting candidates for civil servants is having a color blindness free certificate. It also applies to applicants in several companies and prospective students, especially exact sciences and official schools. Having a pigment problem in the color receptors, people with color blindness will not see as normal people do. The difficulty in seeing specific colors will arise if one of the pigments is missing. Red, green, blue, or a mixture of these colors can be barely seen. People with total color blindness cannot see color at all, even though it is rare [1].

Color blindness testing is usually performed using a color blindness test book. The color blindness test process is commonly carried out manually by showing sheet by sheet of pictures contained in the test book, and the test taker will be asked to state the numbers depicted on the sheets. The answers will reveal whether the participant has normal eyesight or experience partial or even total color blindness. The existing color blindness test books are in the form of paper or bookplates, which will be damaged over time, and even the colors fade due to being difficult to use and hard maintenance [2].

Along with the development of technology, many color blindness testing applications have been developed to facilitate the color blindness test process in which the results will be well documented. Moreover, the level of color resistance of the plates used will not quickly fade because they are digital images packaged in the application. Unfortunately, most of the applications developed cannot be used simultaneously. Nevertheless, they can recapitulate test results for users.

\section{Literature Study}

\section{II.1. Color Blind}

Color blindness is one heredity genetic disorder. In addition to heredity, a person can also experience color blindness caused by consuming drugs for a certain period due to the illness he or she suffers from. The problems encountered by people with color blindness are undoubtedly hard to determine colors. In general, blue, yellow, red, and green will 
be difficult to distinguish. People with normal vision will see many colors, but those with color blindness can only see a few color gradations. The green and red will be difficult to distinguish from a person with color blindness, conversely, yellow and blue can be easily seen. Some people realize that they have color blindness only after carrying out a color blindness test [3].

\section{II.2. Ishihara Method}

In 1927, Dr. Shinobu Ishihara developed the Ishihara test. Globally, this method is an option to identify someone suffering from color blindness. It utilizes a series of tests to detect disturbances in color perception, in the form of a particular color table of a pseudoisochromatic plate composed of dots with different color densities visible for people with normal eyes but will be invisible for those experiencing eye partial color deficiency. It is referred to as color blindness testing using the Ishihara method. The plate is the primary color with a similar color base or gray. The Ishihara test is relatively reliably able to distinguish between weak in green and weak in red [4].

\section{II.3. Previous Studies}

Other researchers have developed similar studies discussing the color blindness test application. Several similar studies that discuss color blind test applications include making simulations to determine the level of color blindness by calculating the distribution of hue, intensity, and saturation values for each test image [5]. Another research is in the form of a color blindness test application using the Ishihara method with the Delphi programming language [6]. Other researchers also use the Delphi programming language in creating a color blindness test application but combining the Ishihara method, the Color Gradation method, and the method. Farnsworth [2]. The next research is making a desktop-based color blindness test application using the Ishihara method using Visual Basic programming [7]. Applications based on Android using the Applying Ishihara method were developed by other researchers [4], [8], [9]. Other researchers created animation for color blindness test simulations using the Ishihara method based on Adobe Flash CS 5 [10]. Creating a color blindness test application using the Ishihara method to simple report recapitulation, faster and easier inspection, and avoiding test results engineered using Visual Basic. NET 10 and SQL Server [11]. From several previous studies, this research builds a mobile-based system that can be used to simultaneously carry out a color blindness test quickly and accurately and recapitulate the test result data of its users using the Ishihara method. This system is equipped with a notification feature. This feature can provide information to all users registered as active members. Information sent can be in the form of health information or others.

\section{Research Method}

This research utilized several stages, as follows:

\section{III.1. System Planning and Requirements}

This step was carried out by searching for and testing several color blindness testing mobile applications researched or designed previously. The analysis results discovered no mobile application system that could be used together and provided a real-time recapitulation of test results. The color blindness testing system built consisted of several components. The first component was a web-based application used to manage the application, while the data in the application were stored in the My Structured Query Language (MySQL) database. Web servers and databases were stored on hosting Niagahoster.

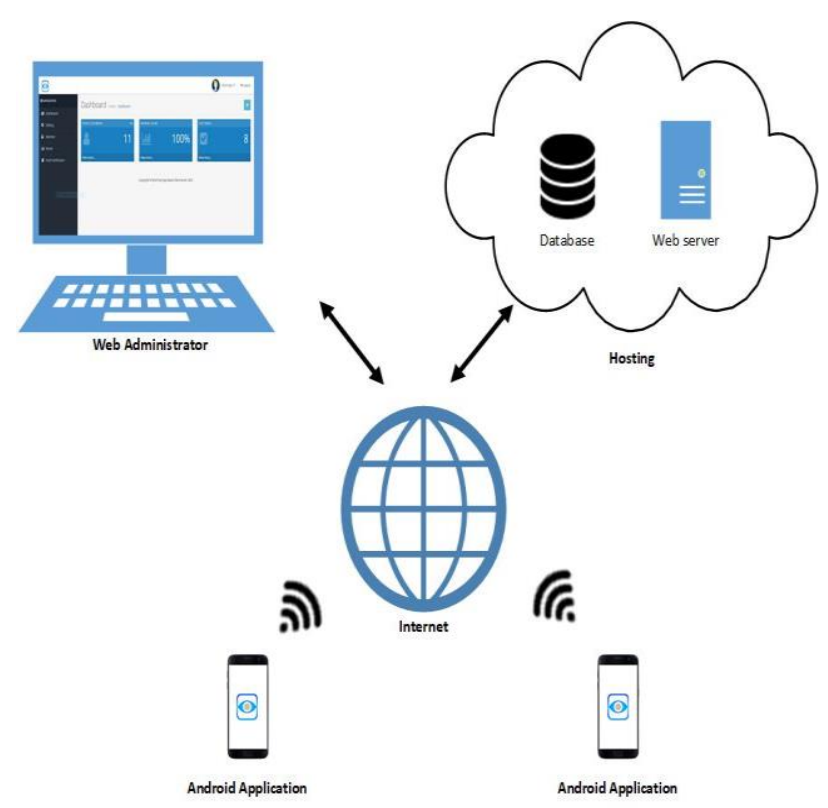

Fig. 1. The architectural design of the color blindness testing application

The second component was an Android-based mobile application installed and used by users when 
conducting a color blindness test. Web services were employed to bridge the two components. Moreover, an internet connection was required to function the application on the user's side. Fig. 1 illustrates the architectural design of a client-server-based color blindness testing application.

\section{III.2. Use Case Diagram}

The use case diagram of the color blindness testing application to be developed involves two actors: the user (the person carrying out the test) and the admin in charge of managing the system. Fig. 2 depicts the use case diagram of a color blindness testing application.

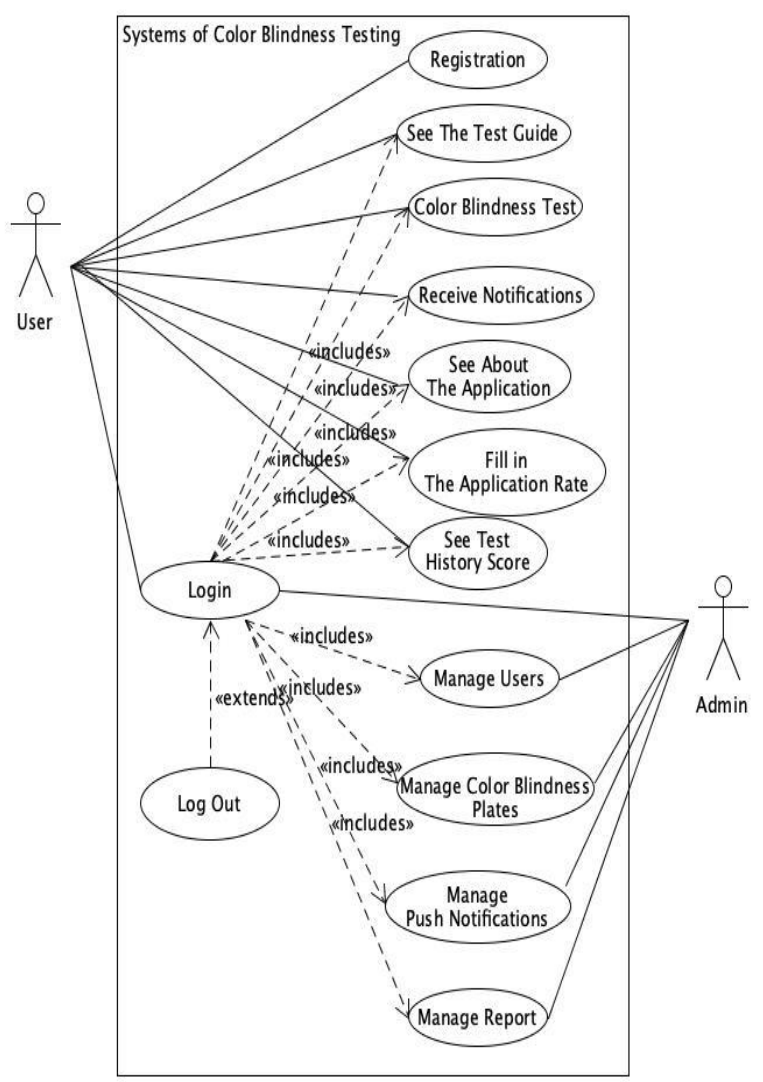

Fig. 2. Use case diagram of the system

\section{III.3. Activity Diagram of The User Takes a Color Blindness Test}

The activity diagram of the user when carrying out a color blindness test illustrates the activity during which the user takes the test until the results are displayed at the end of the test. The activity begins with the user pressing the test option and will be continued with a page containing a guide to carrying out the test. The user begins working on the question and is given 10 seconds. The question will move automatically to the next one. As long as it is within 10 seconds, the user can still change the answer previously selected. The number of questions depends on the recommendations of related parties, for example, doctors, then the admin will enter the questions and answers into the system. After finished, the test results will appear, and the system will save the data according to the user's name. Fig. 3 exhibits the user activity diagram when carrying out a color blindness test.

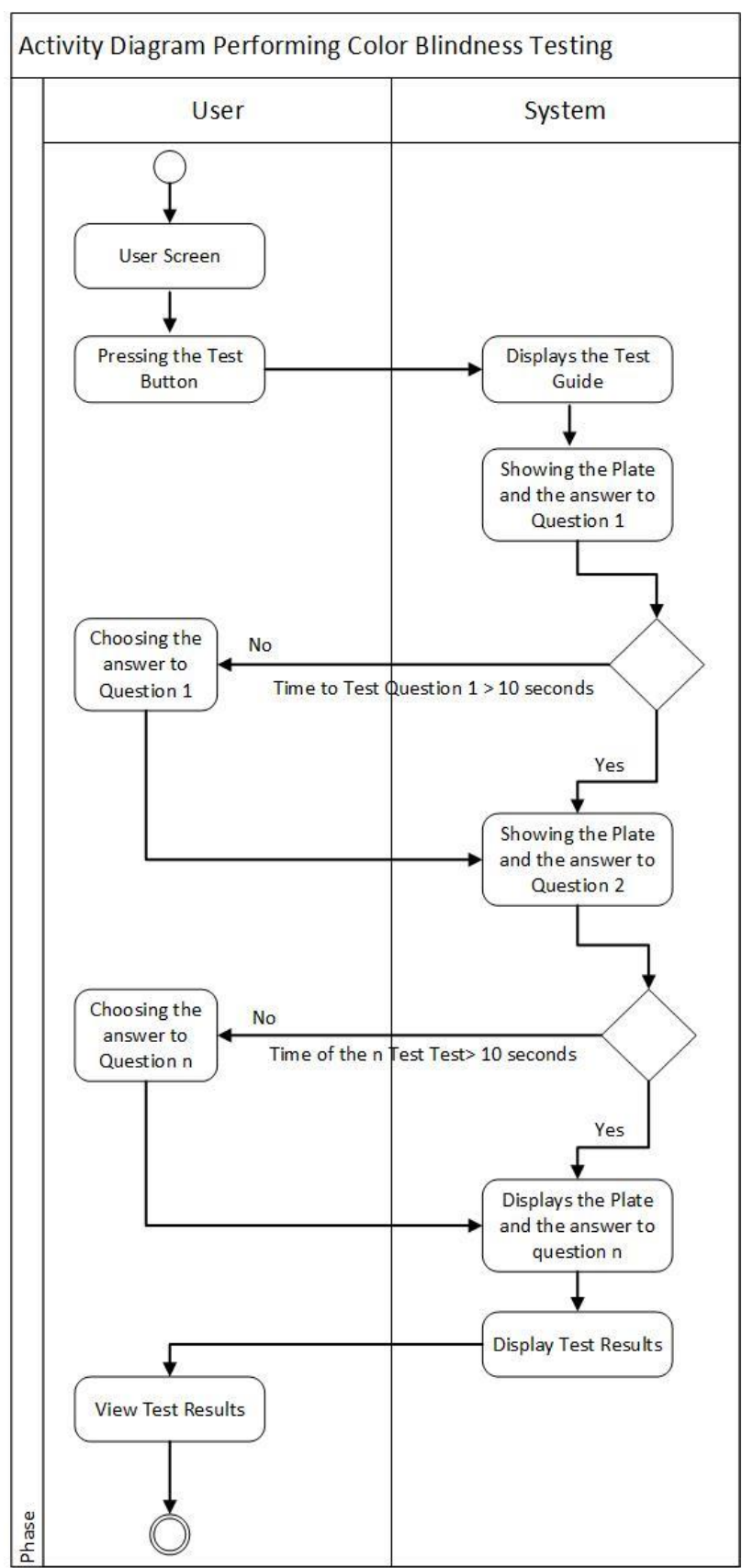

Fig. 3. Activity diagram of the user takes a color blindness test 


\section{Results and Discussion}

The previously created design is implemented through the creation of an Android-based mobile application on the user side and a web application on the admin side.

\section{IV.1. User Application Implementation}

The user-side application can be installed on the minimal version of the Android operating system, namely Ice Cream Sandwich, while in this study, it was installed on the Xiaomi Redmi 5A smartphone using the Nougat version of the android operating system. Internet connection was required to run the application. The display of implementation results on the user side is presented as follows:

1. Color Blindness Application Logo and Splash Screen Display.

This application employed a symbol resembling an eye in which a plate was taken from one of the Ishihara method plates, placing in the middle. This $\operatorname{logo}$ is installed on the application icon, $\log$ in, register portal, and the user's main screen. Before entering the login screen, the user will be presented with a splash screen. The application logo and splash screen display are presented in the following Fig. 4.

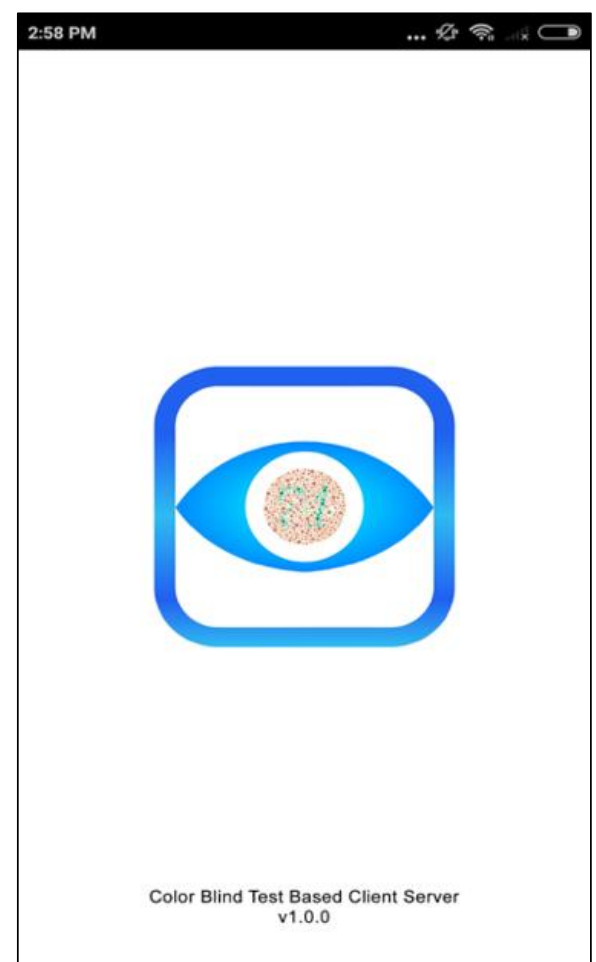

Fig. 4. Splash screen display
2. Login and Register Page Display.

Login and register pages will appear after the splash screen. The user is provided with the option to $\log$ in or register as a member. The display is depicted in Fig. 5 below.

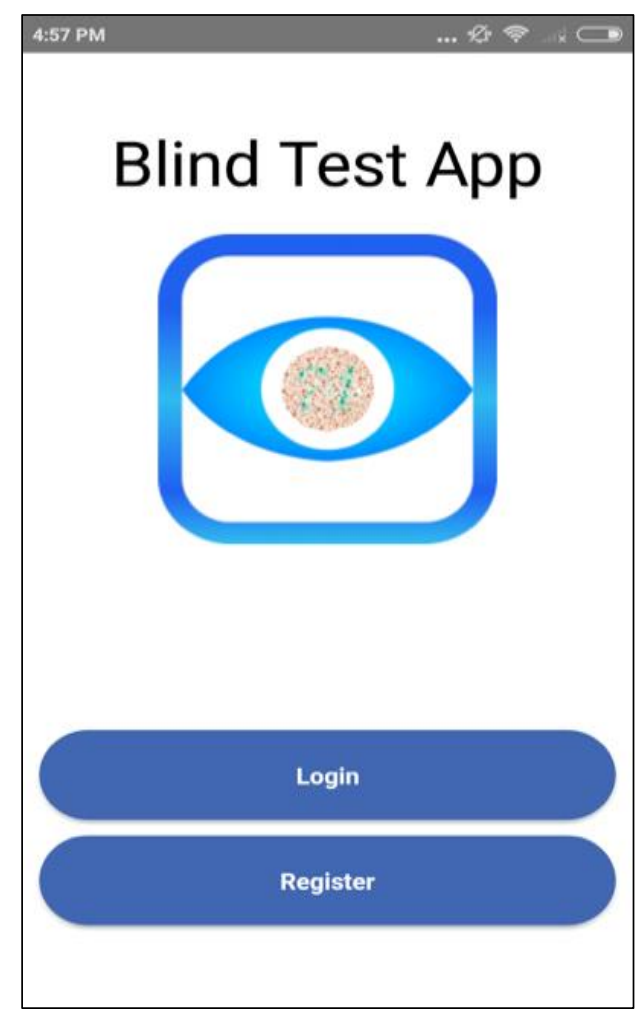

Fig. 5. Login and register page display.

\section{User Dashboard Display.}

The username will appear below the application logo. There are several menus on this page. There is a Test button to run a color blindness test; before working on questions, a guide will appear on how to perform the test. The test results will be displayed at the end, with a score of 100 if all the answers are correct. The History button is used to view the activity values of the tests performed. The 'How To' is used to provide users a guide to carry out tests. Users can see notifications sent via the Notifications button, and information can be in the form of health information or others.

Users can provide an assessment of this application via the Rate button. The last activity is to view information about the application via the About button. Fig. 6 shows the user dashboard after a successful login. 


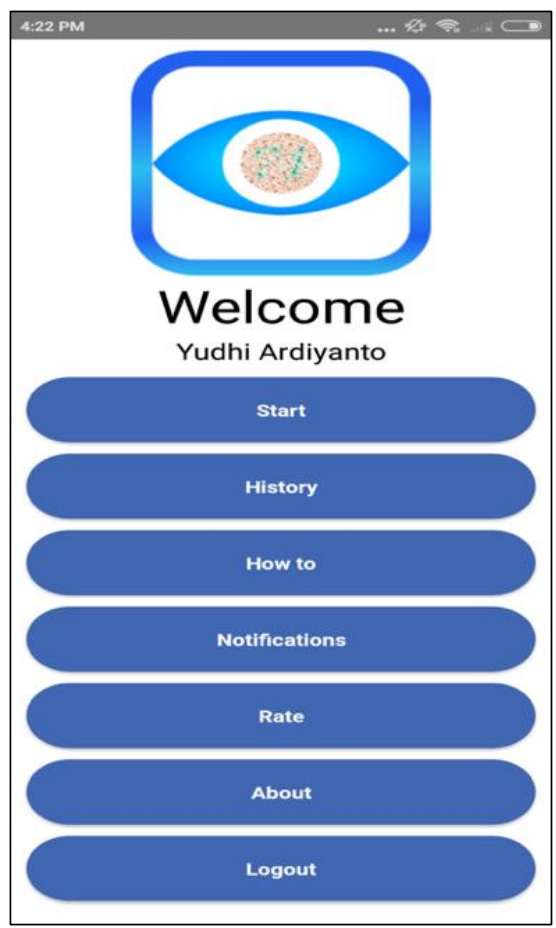

Fig. 6. User dashboard

\section{Test Page Display.}

The test guide always appears at the beginning. The number and order of questions depend on the admin. The number of questions will be displayed on this page. Each question is given 10 seconds of working time; if time is available, the user can change the answer. The question will automatically change to the next one after 10 seconds. This application consisted of four questions by the time it was implemented. Fig. 7 shows the test page.

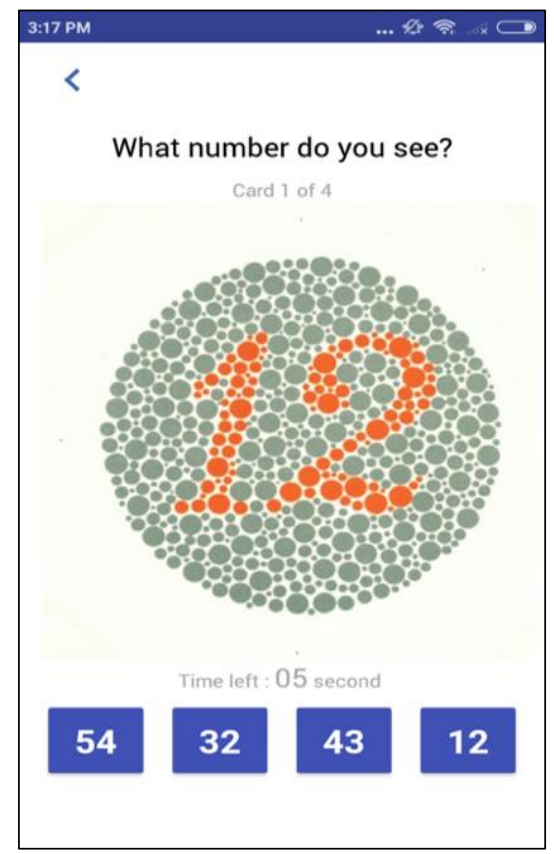

Fig. 7. Test page display

\section{Test Page Display.}

After completing the questions, the test result scores will be displayed. The score is calculated based on the number of correct answers. For example, there are four questions, with three correct answers, then the user will obtain 75 . Two correct answers will obtain score 50, and one correct answer will score 25 . The system of calculating the score of this test can adjust to the number of questions provided. The Next button is used to return to the user dashboard menu. The test score display can be shown in Fig. 8.

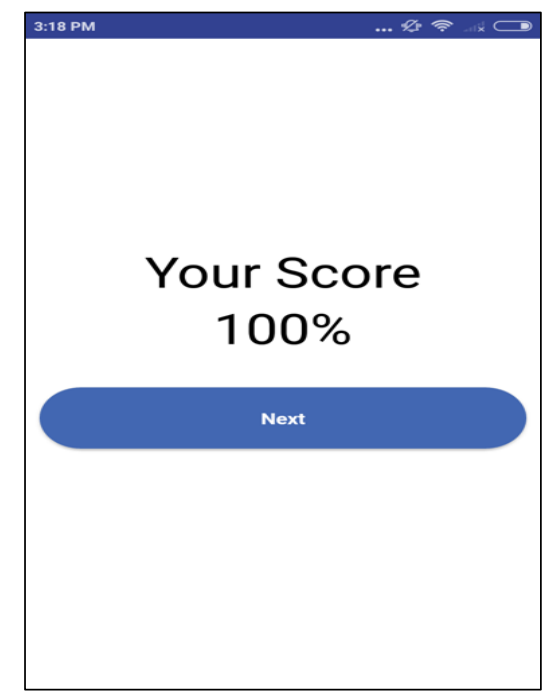

Fig. 8. Test value display

\section{Test History Display.}

Users can view the history of color blindness tests carried out by selecting the history menu.

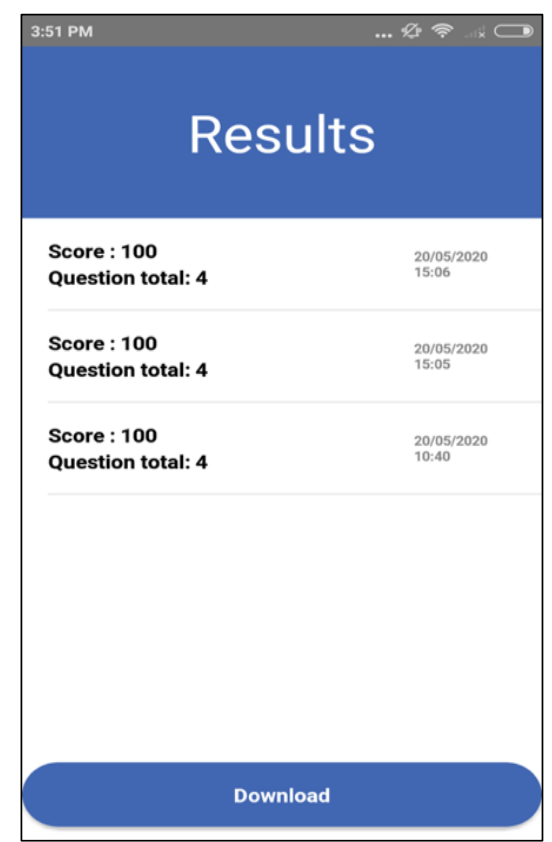

Fig. 9. Test history menu display 
The most recent test is displayed on the first line. The score, time and date, and the number of questions will be displayed in the test history, as shown in Fig. 9.

\section{IV.2. Admin Side Application Implementation}

The application on the admin side is web-based. The display of implementation are as follows:

\section{Admin Login Portal Display.}

The login portal contains a box to enter the username and password to manage the system. After a successful login, the admin dashboard page will appear. The login portal display is presented in Fig. 10.

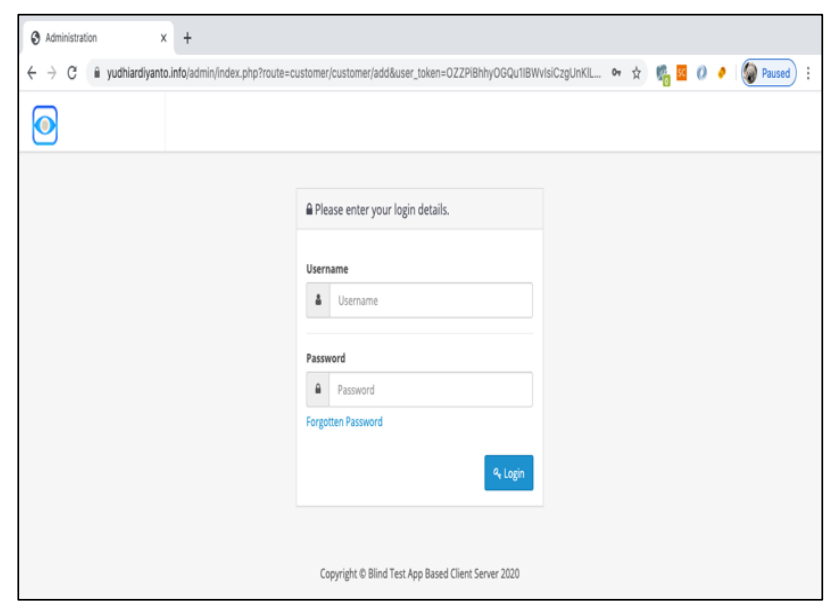

Fig. 10. Admin login portal display

2. Admin Dashboard Display.

Information regarding the number of users or members logged into the system, the average score, and the number of tested members will be displayed upon successful login. On the left, there are several menu options. The Settings menu is used to enter test questions.

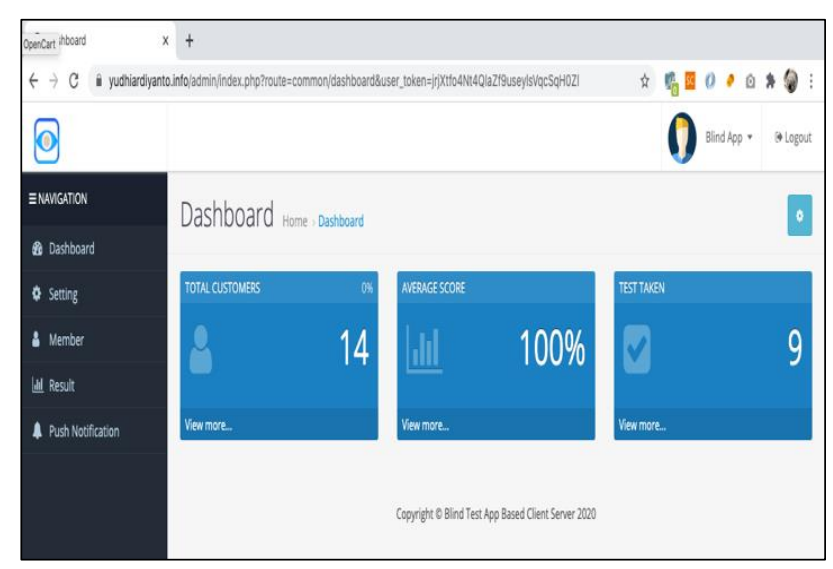

Fig. 11. Admin dashboard display
The Member menu is used to manage members. The Results menu functions to manage the test history of all members. 'Push Notifications' menu functions to send information to all members. The admin dashboard display is portrayed in Fig. 11.

\section{Push Notification Menu Display}

Push Notification menu presented in Fig. 12 functions to send information to all devices having this application installed.

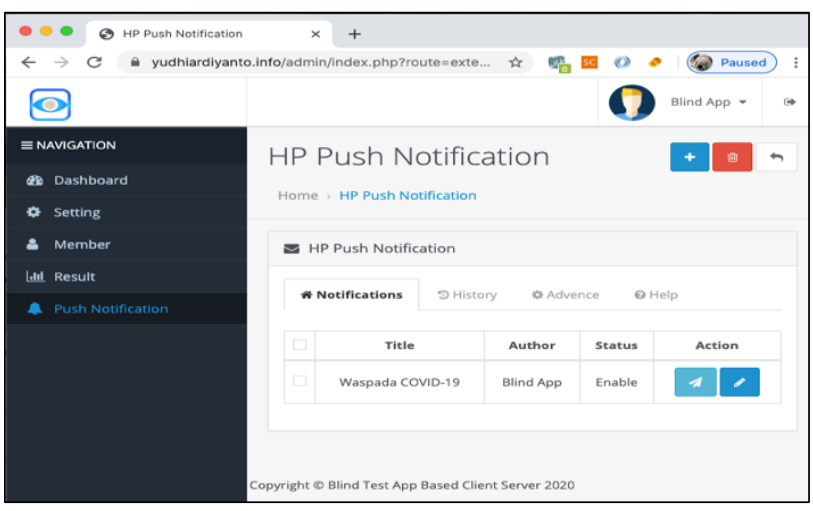

Fig. 12. Push notification menu display

The user will receive a notification, as presented in Fig. 13, and view the information via the notifications menu on the user's main screen.

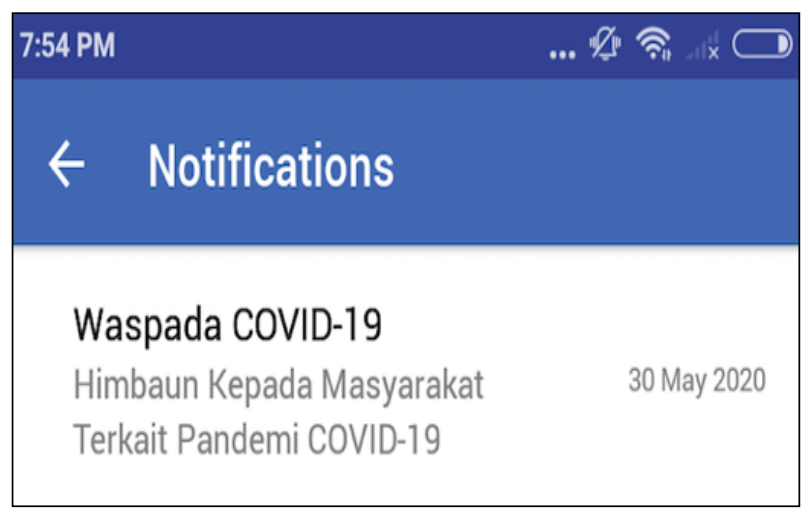

Fig. 13. Notification display in user

\section{Conclusion}

Based on the implementation and testing, it can be concluded that color blindness testing using the client-server-based Ishihara method has worked. The system can provide real-time test results, and detailed test history is presented. Another feature is the push notification menu that sends messages to all users. In the color blindness test application there are facilities for. User's test history is stored in a storage on the system using a database, so that data loss due to damaged or lost paper can be minimized. Storage of 
test history can be seen on the account of each user and can be printed in Portable Document Format (PDF). The development of this application can be done so that it can run on the iPhone Operating System (IOS), because currently it can only run on the Android operating system. In addition, it needs to be developed so that the questions for each user can be displayed randomly.

\section{Acknowledgements}

This work was supported by Universitas Muhammadiyah Yogyakarta.

\section{References}

[1] S. Utami, Seluk Beluk Buta Warna. Yogyakarta: Pustaka Baru Press, 2015.

[2] R. Ardiyan, H. Nasution, and Tursina, "Aplikasi Tes Buta Warna dengan Metode Ishihara Metode Colour Gradation dan Metode Farnsworth," J. Sist. dan Teknol. Inf., vol. 7, no. 4, pp. 250-256, 2019.

[3] W. . Ganong, Buku Ajar Kedokteran, 20th ed. Jakarta, 2013.

[4] D. A. Randy Viyata Dhika, Ernawati, "Aplikasi Tes Buta Warna Dengan Metode Ishihara Pada Smartphone Android," J. Pseucode, vol. 1, no. 1, pp. 51-59, 2014.

[5] R. Kurnia, "Penentuan Tingkat Buta Warna Berbasis His Dengan Banyak Warna Pada Citra Isihara," Semin. Nas. Apl. Teknol. Inf. 2009 (SNATI 2009), vol. IV, no. 1, pp. 54-77, 2009.

[6] H. Murti and R. C. N. Santi, "Aplikasi Pendiagnosa Kebutaan Warna dengan Menggunakan Pemrograman Borland Delphi," Dinamik, vol. 16, no. 2, pp. 160-170, 2011.

[7] D. Abdullah and I. Oktari, "Aplikasi Perancangan Tes Buta Warna Dengan Menggunakan Metode Ishihara," Syntax No 12015, vol. 4, no. x, pp. 1-11, 2012.

[8] S. N. Perdana, Penerapan Metode Ishihara Untuk Perancangan Aplikasi Tes Buta Warna Berbasis Android. 2017.

[9] A. Octaviano and A. Umbari, "Penerapan Metode Ishihara untuk Mendeteksi Buta Warna Sejak Dini Berbasis Android," J. Inform. Univ. Pamulang, vol. 2, no. 1, p. 42, 2017.

[10] D. Ambari and F. Latifah, "Animasi Interaktif Simulasi Tes Buta Warna Dengan Metode Ishihara Berbasis Adobe Flash Cs 5," PETIR, vol. 10, no. 2, pp. 29-36, 2017.

[11] F. N. Efrianty, H. Harsiti, and M. T. Nurhadiyan, "Implementasi Metode Ishihara pada Tes Buta Warna (Colour Deficiency) di Klinik AmandaAnyer," JSiI (Jurnal Sist. Informasi), vol. 5, no. 2, pp. 64-69, 2018.

\section{Authors' information}

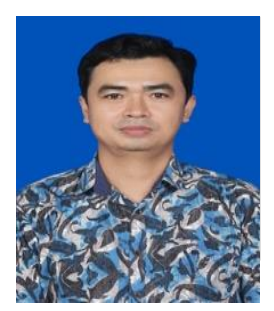

Yudhi Ardiyanto obtained his B.Sc. degree from the Department of Electrical Engineering Universitas Muhammadiyah Yogyakarta and M.Eng. degree from the Department of Electrical Engineering and Informatics Technology, Universitas Gadjah Mada, Yogyakarta, Indonesia. He is a Lecturer in the Department of Electrical Engineering, Faculty of Engineering, Universitas Muhammadiyah Yogyakarta, Indonesia.

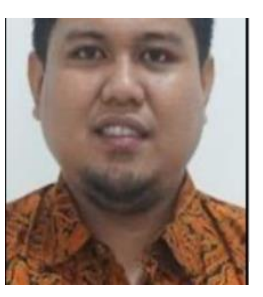

Muhamad Yusvin Mustar obtained his B. Eng in Electrical Engineering from Universitas Muhammadiyah Yogyakarta, Indonesia in 2011. His Master study was done at 2015 at the Electrical Engineering, Universitas Gadjah Mada, Indonesia. He currently is a lecture in Department of Electrical Engineering, Universitas Muhammadiyah Yogyakarta. 